\title{
Corrosion Investigation of Stir Cast Zn-27Al Based Hybrid Composites Reinforced with Quarry Dust and Silicon Carbide Particles
}

\author{
Seun Samuel Owoeye ${ }^{a, b} * \mathbb{0}$, Davies Oladayo Folorunso ${ }^{a}$ \\ ${ }^{a}$ Department of Metallurgical and Materials Engineering, Federal University of Technology, P.M.B. \\ 704, Akure, Nigeria \\ ${ }^{b}$ Department of Glass and Ceramics, Federal Polytechnic, P.M.B. 5351, Ado-Ekiti, Nigeria
}

Received: August 28, 2017; Revised: December 03, 2018; Accepted: April 17, 2019

\begin{abstract}
This paper investigates the corrosion behaviour of Zn-27Al based hybrid composites reinforced with quarry dust $(\mathrm{QD})$ and silicon carbide particles $\left(\mathrm{SiC}_{\mathrm{p}}\right)$. The $\mathrm{Zn}$-27Al hybrid composites containing $8 \mathrm{wt} \%$ and $10 \mathrm{wt} \% \mathrm{SiC}_{\mathrm{p}}$-QD particles reinforcement with varied weight percentage of $0,25,50,75$ and $100 \%$ quarry dust respectively were synthesized using stir casting technique. The corrosion behaviour of the composites was investigated in $0.3 \mathrm{M} \mathrm{H}_{2} \mathrm{SO}_{4}$ and $3.5 \mathrm{wt} \% \mathrm{NaCl}$ solution at $25^{\circ} \mathrm{C}$ using electrochemical methods in accordance with ASTM G59-97(2014) standard. The results show that for $8 \mathrm{wt} \%$ reinforcement, the hybrid composites $\mathrm{A}_{2}$ and $\mathrm{A}_{3}$ (corresponding to $50 \% \mathrm{SiC}_{\mathrm{p}}: 50 \% \mathrm{QD}$ and $25 \% \mathrm{SiC}_{\mathrm{p}}: 75 \% \mathrm{QD}$ respectively) having corrosion rate of $0.006 \mathrm{mmpy}$ displayed superior corrosion resistance. For $10 \mathrm{wt} \%$ reinforcement, hybrid grades $\mathrm{B}_{1}\left(75 \% \mathrm{SiC}_{\mathrm{p}}: 25 \% \mathrm{QD}\right) \mathrm{B}_{2}\left(50 \% \mathrm{SiC}_{\mathrm{p}}: 50 \%\right.$ $\mathrm{QD})$ and $\mathrm{B}_{3}\left(25 \% \mathrm{SiC}_{\mathrm{p}}: 75 \% \mathrm{QD}\right)$ has superior corrosion rate of $0.0172,0.0126$ and $0.0135 \mathrm{mmpy}$ respectively while $\mathrm{B}_{4}$ (corresponding to $100 \% \mathrm{QD}$ ) shows the most superior corrosion rate of 0.00315 mmpy when compared with the monolithic alloy having corrosion rate of $0.213 \mathrm{mmpy}$ all in marine environment ( $3.5 \mathrm{wt} \% \mathrm{NaCl}$ solution). However, except for composite grade $\mathrm{A}_{2}$ with $0.055 \mathrm{mmpy}$ corrosion rate and $\mathrm{B}_{4}$ (corresponding to $100 \% \mathrm{QD}$ ) with superior corrosion rate of $0.0143 \mathrm{mmpy}$ in $0.3 \mathrm{M} \mathrm{H}_{2} \mathrm{SO}_{4}$ medium, all other composite grades performed poorly in the acidic medium.
\end{abstract}

Keywords: Zn-27Al alloy based composites, Stir Casting, Corrosion, Silicon carbide, Quarry dust.

\section{Introduction}

$\mathrm{Zn}-27 \mathrm{Al}$ belongs to a family of zinc alloys which are commercially referred to as ZA alloys designated by ZA-8, ZA-12 and ZA-27 corresponding to approximate aluminum content in the alloys. Zn-27Al alloy with a nominal content of $27 \mathrm{wt} \%$ aluminum has been reported to offer good strength, low density, excellent bearing capability, wear resistance, favourable combination of physical, mechanical and technological properties as well as better corrosion resistance of all the ZA alloys ${ }^{1-2}$

Corrosion features of the as-cast $\mathrm{Zn}-27 \mathrm{Al}$ alloy has been studied and reported ${ }^{3-4}$ indicating the presence of aluminum to have favourable effect on its corrosion behaviour. $\mathrm{Zn}$ $27 \mathrm{Al}$ shows high resistance to corrosion in atmospheric exposure, natural waters, soils as well as wide range of chemical environments due to the ability of the zinc to form a passive (protective) layer of corrosion products at the surface comprising mainly of zinc oxide $(\mathrm{ZnO})$, zinc hydroxide $\left(\mathrm{Zn}(\mathrm{OH})_{2}\right)$, simonkolleite or their mixtures ${ }^{5,3}$. The most common form of corrosion prevalent in $\mathrm{Zn}-27 \mathrm{Al}$ in a variety of natural environments is uniform corrosion ${ }^{3}$. However, there has been a lack of specific corrosion data on zinc-aluminum based metal matrix composites and their corrosion resistance to date, due to the limited application of these alloys as matrix material for metal matrix composites ${ }^{6}$.

"e-mail: owoeyeseun@gmail.com
Hard reinforcements such as alumina $\left(\mathrm{Al}_{2} \mathrm{O}_{3}\right)$, silicon carbide $(\mathrm{SiC})$, zirconia $(\mathrm{Zr})$, and graphite $\left(\mathrm{C}_{\mathrm{g}}\right)$ have been successfully utilized as a whole or to form hybrid which result into enormous property enhancement to enrich the strength, hardness, elastic modulus, and wear resistance of $\mathrm{Zn}-27 \mathrm{Al}$ while other properties such as damping capacity, fracture toughness, impact resistance, and corrosion resistance have been improved ${ }^{7-8,6}$. The inclusion of the reinforcing particles and fibers as well as the fabrication methods associated with metal matrix composites can influence the corrosion resistance of the metal matrix ${ }^{6}$.

During the past few decades, several authors have investigated the corrosion behavior of ZA-27 alloy based metal matrix composites ${ }^{9-13}$.

Seah et al ${ }^{9}$ investigated the corrosion characteristics of ZA-27 alloy reinforced with graphite particles in $\mathrm{HCl}$ solution and SAE 40 oil respectively which was aimed at exploring the possibility of using the composite in such acidic environments and also to evaluate the composite as a bearing material. The results however showed that the ZA-27/graphite particles composites corrode in $\mathrm{HCl}$ solution but not in SAE 40 oil. They also observed that corrosion resistance increases with increasing graphite particles. The effect of zircon particles on the corrosion characteristics of ZA-27/zircon particles composites in $\mathrm{HCl}$ was also reported by Sharma et al ${ }^{10}$. The results revealed that material loss was due to pit formation which was developed at matrix/ 
particle interface induced by cracked. However, corrosion resistant of the composites increases with increase in zircon content. An attempt was also made by ${ }^{11}$ to examine the corrosion behavior of ZA-27 alloy reinforced with glass fibers in $\mathrm{HCl}$ solution. The composite was developed using compo casting technique and the corrosion test conducted under room temperature using weight loss method. In order to substantiate the difference between the corrosion behavior of heat-treated and as-cast specimens, some composite specimens were heat treated at $320^{\circ} \mathrm{C}$ for 2,3 , and $4 \mathrm{hrs}$ respectively. The results showed that corrosion rate seems to decrease with time of corrosion test which might be attributed to the presence of aluminum in the matrix ZA-27 alloy. The corrosion rate also decreases monotonically with increasing glass fiber contents which might be as a result of the glass fiber inertness. However, the heat-treated samples showed an improvement in corrosion resistance was also. Bobic et $a l^{12}$ also evaluated the corrosion behavior of as-cast and heat-treated ZA-27 alloy in $\mathrm{NaCl}$ solution. The immersion test and polarization resistance measurements were used to assess the corrosion behavior of the ZA-27 alloy as-cast and heat-treated specimens in accordance with ASTM G31 standard. It was observed that T4 heat treatment applied has small beneficial effect on the corrosion resistance of ZA-27 alloy. Investigation was also carried out by ${ }^{13}$ on the corrosion behavior of compo cast $\mathrm{ZA}-27 / \mathrm{SiC}_{\mathrm{p}}$ composites in $\mathrm{NaCl}$ solution. The corrosion rate was determined using the conventional weight loss measurement in accordance with ASTM G31 standard. It was observed that a uniform corrosion occurred at the surface; however, the corrosion resistance of the $\mathrm{ZA}-27 / \mathrm{SiC}_{\mathrm{p}}$ is lower compared to the matrix alloy. According to the results obtained ${ }^{9-13}$, the corrosion resistance of ZA-27 alloy based metal matrix composites increases with the enhancement of reinforcing phase content in the composite material; the corrosion rate was also found to decrease with time.

In this present work, attempt is made to investigate the corrosion behavior of stir cast ZA-27 alloy based hybrid composites reinforced with silicon carbide and quarry dust particles in sodium chloride and sulfuric acid solutions respectively which has not been studied yet. This work is motivated by the prospect of developing low cost-high performance ZA-27 alloy matrix hybrid composites using quarry dust particles as reinforcements with comparable properties with those reinforced with solely $\mathrm{SiC}_{\mathrm{p}}$ which is a more expensive material.

\section{Material and Methods}

\subsection{Materials}

The materials used for the production of ZA-27 alloy selected as base matrix in accordance with ASTM B669-82 for the produced composites are commercial zinc (with chemical composition presented in Table 1) and aluminum 6063 (with chemical composition presented in Table 2 ). Chemically pure silicon carbide $\left(\mathrm{SiC}_{\mathrm{p}}\right)$ of particle size $30 \mu \mathrm{m}$ and stone dust particles $(<38 \mu \mathrm{m})$ were selected as reinforcing materials for the production of the composites. The chemical composition of the stone dust taken into study in accordance with ${ }^{14}$ is $\mathrm{SiO}_{2}-62.48 \%, \mathrm{Al}_{2} \mathrm{O}_{3}-18.72 \%, \mathrm{Fe}_{2} \mathrm{O}_{3}-6.54 \%, \mathrm{MgO}-2.56 \%$, $\mathrm{CaO}-4.83 \%, \mathrm{~K}_{2} \mathrm{O}-3.18 \%, \mathrm{TiO}_{2}-1.21 \%$.

Table 1. Samples Designation for the produced ZA-27 Composites

\begin{tabular}{cc}
\hline Samples Designation & Wt.\% $_{\left(\mathbf{S i C}_{\mathbf{p}}: \mathbf{Q D}\right)}$ \\
\hline $\mathbf{8}$ wt\% Reinforcement & $100: 0$ \\
$\mathrm{~A}_{0}$ & $75: 25$ \\
$\mathrm{~A}_{1}$ & $50: 50$ \\
$\mathrm{~A}_{2}$ & $25: 75$ \\
$\mathrm{~A}_{3}$ & $0: 100$ \\
$\mathrm{~A}_{4}$ & \\
$\mathbf{1 0} \mathbf{w t} \%$ Reinforcement & $100: 0$ \\
$\mathrm{~B}_{0}$ & $75: 25$ \\
$\mathrm{~B}_{1}$ & $50: 50$ \\
$\mathrm{~B}_{2}$ & $25: 75$ \\
$\mathrm{~B}_{3}$ & $0: 100$ \\
$\mathrm{~B}_{4}$ &
\end{tabular}

Table 2. Electrochemical data of the unreinforced and reinforced ZA-27 alloy composites from the tafel extrapolations in $3.5 \mathrm{wt} \%$ $\mathrm{NaCl}$ solution

\begin{tabular}{|c|c|c|c|}
\hline Sample & $\mathbf{E}_{\text {corr }}(\mathbf{m V})$ & $I_{\text {corr }}(\mu \mathbf{A})$ & $\begin{array}{l}\text { Corrosion } \\
\text { rate } \\
(\mathrm{mmpy})\end{array}$ \\
\hline $\begin{array}{l}\text { Control (unreinforced } \\
\text { Zn-27Al) }\end{array}$ & -860.59 & -14.208 & 0.21289 \\
\hline \multicolumn{4}{|l|}{$\begin{array}{l}\text { For } 8 \mathrm{wt} \% \\
\text { reinforcement }\end{array}$} \\
\hline $\mathrm{A}_{0}\left(\mathrm{Zn}-27 \mathrm{Al}-100 \% \mathrm{SiC}_{\mathrm{p}}\right)$ & -800.544 & -539.539 & 0.008084 \\
\hline $\begin{array}{l}\mathrm{A}_{1}\left(\mathrm{Zn}-27 \mathrm{Al}-75 \% \mathrm{SiC}_{\mathrm{p}}:\right. \\
25 \% \mathrm{QD})\end{array}$ & -761.927 & -1.587 & 0.023789 \\
\hline $\begin{array}{l}\mathrm{A}_{2}\left(\mathrm{Zn}-27 \mathrm{Al}-50 \% \mathrm{SiC}_{\mathrm{p}}:\right. \\
50 \% \mathrm{QD})\end{array}$ & -988.12 & -429.087 & 0.0064291 \\
\hline $\begin{array}{l}\mathrm{A}_{3}\left(\mathrm{Zn}-27 \mathrm{Al}-25 \% \mathrm{SiC}_{\mathrm{p}}:\right. \\
75 \% \mathrm{QD})\end{array}$ & -988.12 & -429.087 & 0.0064291 \\
\hline $\mathrm{A}_{4}(\mathrm{Zn}-27 \mathrm{Al}-100 \% \mathrm{QD})$ & -1.006 & -1.313 & 0.019676 \\
\hline \multicolumn{4}{|l|}{$\begin{array}{l}\text { For } 10 \mathrm{wt} \% \\
\text { reinforcement }\end{array}$} \\
\hline $\mathrm{B}_{0}\left(\mathrm{Zn}-27 \mathrm{Al}-100 \% \mathrm{SiC}_{\mathrm{p}}\right)$ & -785.048 & -2.331 & 0.034938 \\
\hline $\begin{array}{l}\mathrm{B}_{1}\left(\mathrm{Zn}-27 \mathrm{Al}-75 \% \mathrm{SiC}_{\mathrm{p}}:\right. \\
25 \% \text { QD }\end{array}$ & -781.903 & -1.147 & 0.017193 \\
\hline $\begin{array}{l}\mathrm{B}_{2}\left(\mathrm{Zn}-27 \mathrm{Al}-50 \% \mathrm{SiC}_{\mathrm{p}}:\right. \\
50 \% \text { QD) }\end{array}$ & -902.006 & -846.159 & 0.012678 \\
\hline $\begin{array}{l}\mathrm{B}_{3}\left(\mathrm{Zn}-27 \mathrm{Al}-25 \% \mathrm{SiC}_{\mathrm{p}}:\right. \\
75 \% \text { QD) }\end{array}$ & -769.092 & -903.748 & 0.013541 \\
\hline $\mathrm{B}_{4}(\mathrm{Zn}-27 \mathrm{Al}-100 \% \mathrm{QD})$ & -908.679 & -210.749 & 0.0031577 \\
\hline
\end{tabular}




\subsection{Production of Zn-27Al alloy based Composites}

Double stir casting method was utilized in accordance with ${ }^{15}$ and ${ }^{16}$ for the production of the composites in the course of this research. The appropriate amount of silicon carbide and stone dust to prepare $8 \mathrm{wt} \%$ and $10 \mathrm{wt} \%$ reinforcements in the $\mathrm{Zn}$-Al alloy matrix respectively was determined using charge calculations. Five different stone dust-silicon carbide $\left(\mathrm{SD}-\mathrm{SiC}_{\mathrm{p}}\right.$ ) reinforcement weight mix ratios were prepared consisting of $0,25,50,75$ and $100 \%$ stone dust respectively. In order to remove the moisture content and improves wettability between the reinforcing materials and the zinc-aluminum alloy melt, the silicon carbide and stone dust was initially pre-heated respectively at a temperature of $250^{\circ} \mathrm{C}$ according to ${ }^{17}$.

The Aluminum (6063) billet was first accurately weighed and charged inside a gas fired lift out crucible with a fitted temperature probe to monitor the temperature, and fired to a temperature of $670^{\circ} \mathrm{C}$ until a molten aluminum is obtained. The furnace temperature was later reduced to about $500^{\circ} \mathrm{C}$ before weighed zinc was introduced into the crucible and allowed to completely melt. The molten $\mathrm{Zn}-\mathrm{Al}$ alloy obtained was then allowed to cool inside the furnace to a semi-solid state (at a temperature of about $450^{\circ} \mathrm{C}$ ); after which it was well stirred with using mechanical stirrer for 5 minutes at $200 \mathrm{rpm}$ to attain homogenization. The pre-heated weighed silicon carbide and stone dust particles were then charged inside the melt and the resulting slurry stirred manually for about 5-10 minutes while a small amount of Borax was introduced as wetting agent to enhance further wettability of the reinforcing materials with the molten alloy as stated by ${ }^{18}$. The resulting composite slurry was then superheated to $530^{\circ} \mathrm{C}$ and second stirring conducted with the aid of mechanical stirrer. The stirring operation was carried out for 10 minutes at $400 \mathrm{rpm}$ before pouring into the prepared sand molds to obtain cast composites. The sample designations for the different compositions of the produced ZA-27 alloy based hybrid composites are shown in Table 1.

\subsection{Corrosion analysis}

Corrosion testing was conducted using electrochemical methods in accordance with ASTM G59-97 (2014) standard. The experiments were carried out using an AutoLAb potentiostat (Versa STAT 400) with versa STUDIO electrochemical software. Corrosion behavior of the samples was investigated in $0.3 \mathrm{M} \mathrm{H}_{2} \mathrm{SO}_{4}$ and $3.5 \% \mathrm{wt} \mathrm{NaCl}$ solution at room temperature $\left(25^{\circ} \mathrm{C}\right)$. The experiments were performed using a three electrode corrosion cell set-up comprising the sample (ZA-27 Alloy) as the working electrode, saturated silver/silver chloride as reference electrode, and platinum as counter electrode. The working electrodes were prepared by attaching an insulated copper wire to one face of the sample using aluminum conducting tape, and cold mounting it with epoxy resin. The working electrode was immersed in test solutions $\left(0.3 \mathrm{M} \mathrm{H}_{2} \mathrm{SO}_{4}\right.$ and $\left.3.5 \mathrm{wt} \% \mathrm{NaCl}\right)$ until a stable open circuit potential was obtained. Open-circuit corrosion potential (OCP) measurements were carried out in a separate cell for 120 minutes whereas potentiodynamic polarization measurements were carried out using a scan rate of $0.25 \mathrm{mV} / \mathrm{s}$ at a potential initiated at $-250 \mathrm{mV}$ to $+250 \mathrm{mV}$ with respect to OCP. After each experiment, the electrolyte and the test samples was replaced. The linear Tafel segments of the anodic and cathodic curves were extrapolated to corrosion current densities $\left(\mathrm{I}_{\text {corr }}\right)$ and corrosion potential $\left(\mathrm{E}_{\text {corr }}\right)$. Three repeat tests were carried out for all alloy compositions, and the reproducibility and repeatability were observed to be good as there were no significant differences between results from triplicates.

\section{Results and Discussion}

\subsection{Corrosion behavior in marine $(3.5 \mathrm{wt} \% \mathrm{NaCl}$ ) environment}

The corrosion results obtained from the tafel plots electrochemical studies in $3.5 \mathrm{wt} \% \mathrm{NaCl}$ are presented in Figure 1 while the tafel extrapolations of the corrosion current densities $\left(\mathrm{I}_{\text {corr }}\right)$ and corrosion potentials $\left(\mathrm{E}_{\text {corr }}\right)$ which are presented in Table 2 indicate clear distinct corrosion behavior between the unreinforced and reinforced ZA-27 composites grades. From Figure 1, for $8 \mathrm{wt} \%$ reinforcement, it can be observed that the reinforced composites grade $\mathrm{A}$ series show better corrosion resistance in the salt environment compared with the unreinforced ZA-27 alloy having corrosion rate of $0.213 \mathrm{mmpy}$, however, hybrid composites grade $\mathrm{A}_{2}$ and $\mathrm{A}_{3}$ (corresponding to $50 \% \mathrm{SiC}_{\mathrm{p}}$ : $50 \%$ QD and $25 \%$ $\mathrm{SiC}_{\mathrm{p}}:$ 75\% QD respectively) with corrosion rate of 0.006 mmpy displayed superior corrosion resistance which might be attributed to the corrosion products forming a tenacious

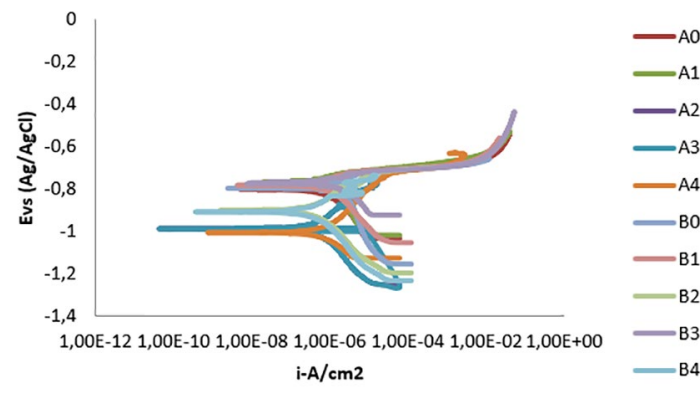

Figure 1. Polarization curves of unreinforced and reinforced ZA-27 alloy composites in $3.5 \mathrm{wt} \% \mathrm{NaCl}$ solution 
protective layers on the samples ${ }^{19}$. The combining effects of $\mathrm{QD} / \mathrm{SiC}$ particles might also slow down the dissolution of the matrix material as observed in the hybrid samples ${ }^{20}$. This is however showing the beneficial effects of quarry dust as partial or sole replacement to $\mathrm{SiC}_{\mathrm{p}}$.

For $10 \mathrm{wt} \%$ reinforcement, it can be observed that all the composite grade $\mathrm{B}$ series also displayed better corrosion resistance. The hybrid grades $\mathrm{B}_{1}\left(75 \% \mathrm{SiC}_{\mathrm{p}}: 25 \% \mathrm{SD}\right), \mathrm{B}_{2}$ $\left(50 \% \mathrm{SiC}_{\mathrm{p}}: 50 \% \mathrm{QD}\right)$ and $\mathrm{B}_{3}\left(25 \% \mathrm{SiC}_{\mathrm{p}}: 75 \% \mathrm{QD}\right)$ has superior corrosion rate of $0.0172,0.0126$ and $0.0135 \mathrm{mmpy}$ respectively as compared with $\mathrm{B}_{0}$ (corresponding to $100 \%$ $\mathrm{SiC}_{\mathrm{p}}$ reinforcement) while $\mathrm{B}_{4}$ (corresponding to $100 \% \mathrm{QD}$ ) shows the most superior corrosion rate of $0.00315 \mathrm{mmpy}$. This good behavior observed might be due to increase in grain boundaries offered by the hybrid particles, thereby resulting to decrease in the depth of corrosion penetration ${ }^{20}$ while the superior corrosion resistance observed in $\mathrm{B}_{4}$ which is solely reinforced by quarry dust might be due to the resistivity or inertness of the quarry dust.

\subsection{Corrosion behaviour in acidic $\left(0.3 \mathrm{M} \mathrm{H}_{2} \mathrm{SO}_{4}\right)$ environment}

The corrosion results obtained from the tafel plots electrochemical studies in $0.3 \mathrm{M} \mathrm{H}_{2} \mathrm{SO}_{4}$ are presented in Figure 2 while the tafel extrapolations of the corrosion current densities $\left(\mathrm{I}_{\text {corr }}\right)$ and corrosion potentials $\left(\mathrm{E}_{\text {corr }}\right)$ which are presented in Table 3 indicate clear distinct corrosion behaviour between the unreinforced and reinforced ZA-27 composites grades. From Figure 2 it can be observed that all the composites grade series A and B did not perform well in the acidic environment except for composite grade $\mathrm{A}_{2}$ with 0.055 mmpy corrosion rate while the overall superior corrosion rate of $0.0143 \mathrm{mmpy}$ was observed with $\mathrm{B}_{4}$ (corresponding to $100 \% \mathrm{QD}$ ) showing similar trend observed in salt environment which indicates better resistivity of quarry dust in the corrosion media. This poor behaviour of monolithic and reinforced composites in acid media has generally been observed and reported by several researchers.

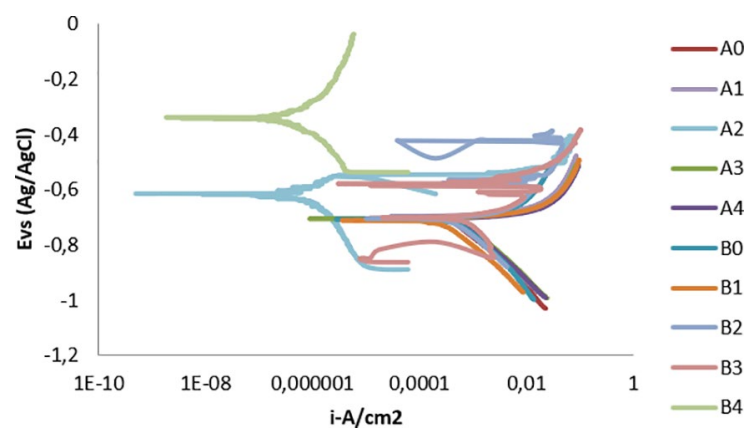

Figure 2. Polarization curves of unreinforced and reinforced ZA-27 alloy composites in $0.3 \mathrm{M} \mathrm{H}_{2} \mathrm{SO}_{4}$ solution
Table 3. Electrochemical data of the unreinforced and reinforced ZA-27 alloy composites from the tafel extrapolations in $0.3 \mathrm{M}$ $\mathrm{H}_{2} \mathrm{SO}_{4}$ solution

\begin{tabular}{|c|c|c|c|}
\hline Sample & $\mathrm{E}_{\text {corr }}(\mathrm{mV})$ & $\mathrm{I}_{\text {corr }}(\mu \mathrm{A})$ & $\begin{array}{c}\text { Corrosion } \\
\text { rate }(\mathrm{mmpy})\end{array}$ \\
\hline $\begin{array}{l}\text { Control (unreinforced } \\
\text { Zn-27Al) }\end{array}$ & -704.661 & 281.212 & 4.2135 \\
\hline \multicolumn{4}{|l|}{$\begin{array}{l}\text { For } 8 \mathrm{wt} \% \\
\text { reinforcement }\end{array}$} \\
\hline $\begin{array}{l}\mathrm{A}_{0}(\mathrm{Zn}-27 \mathrm{Al}-100 \% \\
\left.\mathrm{SiC}_{\mathrm{p}}\right)\end{array}$ & -704.933 & -378.23 & 5.6671 \\
\hline $\begin{array}{l}\mathrm{A}_{1}(\mathrm{Zn}-27 \mathrm{Al}- \\
\left.75 \% \mathrm{SiC}_{\mathrm{p}}: 25 \% \mathrm{SD}\right)\end{array}$ & -699.172 & -566.503 & 8.488 \\
\hline $\begin{array}{l}\mathrm{A}_{2}(\mathrm{Zn}-27 \mathrm{Al}- \\
\left.50 \% \mathrm{SiC}_{\mathrm{p}}: 50 \% \mathrm{SD}\right)\end{array}$ & -618.056 & -3.704 & 0.055506 \\
\hline $\begin{array}{l}\mathrm{A}_{3}(\mathrm{Zn}-27 \mathrm{Al}- \\
\left.25 \% \mathrm{SiC}_{\mathrm{p}}: 75 \% \mathrm{SD}\right)\end{array}$ & -705.576 & -578.523 & 8.6681 \\
\hline $\begin{array}{l}\mathrm{A}_{4}(\mathrm{Zn}-27 \mathrm{Al}-100 \% \\
\mathrm{SD})\end{array}$ & -708.555 & -523.784 & 7.848 \\
\hline \multicolumn{4}{|l|}{$\begin{array}{l}\text { For } 10 \mathrm{wt} \% \\
\text { reinforcement }\end{array}$} \\
\hline $\begin{array}{l}\mathrm{B}_{0}(\mathrm{Zn}-27 \mathrm{Al}-100 \% \\
\left.\mathrm{SiC}_{\mathrm{p}}\right)\end{array}$ & -710.388 & -528.114 & 7.9128 \\
\hline $\begin{array}{l}\text { B1 (Zn-27Al- 75\% } \\
\text { SiCp: } 25 \% \text { SD) }\end{array}$ & -717.992 & -432.52 & 6.4806 \\
\hline $\begin{array}{l}\mathrm{B}_{2}(\mathrm{Zn}-27 \mathrm{Al}-50 \% \\
\left.\mathrm{SiC}_{\mathrm{p}}: 50 \% \mathrm{SD}\right)\end{array}$ & -711.518 & -487.182 & 7.2996 \\
\hline $\begin{array}{l}\mathrm{B}_{3}(\mathrm{Zn}-27 \mathrm{Al}-25 \% \\
\left.\mathrm{SiC}_{\mathrm{p}}: 75 \% \mathrm{SD}\right)\end{array}$ & -702.269 & -1.03 & 15.564 \\
\hline $\begin{array}{l}\mathrm{B}_{4}(\mathrm{Zn}-27 \mathrm{Al}- \\
100 \% \mathrm{SD})\end{array}$ & -314.474 & -985.942 & 0.014773 \\
\hline
\end{tabular}

\section{Conclusions}

The corrosion behavior of stir cast ZA-27 based hybrid composites containing 8 and $10 \mathrm{wt} \%$ varied proportion of quarry dust $(\mathrm{QD})$ and silicon carbide $\left(\mathrm{SiC}_{\mathrm{p}}\right)$ respectively was investigated. The results show that:

- The corrosion behavior for both $8 \mathrm{wt} \%$ and $10 \mathrm{wt} \%$ reinforced composites show that all the composites displayed superior corrosion behavior when compared with monolithic alloy in $3.5 \mathrm{wt} \% \mathrm{NaCl}$ environment while they all perform poorly in $0.3 \mathrm{M} \mathrm{H}_{2} \mathrm{SO}_{4}$ environment except for composites grade $\mathrm{A}_{2}$ and $\mathrm{B}_{4}$.

- Composite grade $\mathrm{B}_{4}$ (corresponding to $100 \% \mathrm{QD}$ ) displayed overall superior corrosion rate both in $3.5 \mathrm{wt} \% \mathrm{NaCl}$ and $0.3 \mathrm{M} \mathrm{H}_{2} \mathrm{SO}_{4}$ justifying the potential of stone dust particles to be use as a partial or sole replacement for $\mathrm{SiC}_{\mathrm{p}}$ in metal composites development in corrosive media. 


\section{References}

1. Chen T, Yuan C, Fu M, Ma Y, Li Y, Hao Y. Friction and wear properties of casting in-situ silicon particle reinforced ZA27 composites. China Foundry. 2009;6(1):1-8.

2. Karni N, Barkay GB, Bamberger M. Structure and properties of metal-matrix composite. Journal of Materials Science Letters. 1994;13:541-544.

3. Porter FC. Corrosion Resistance of Zinc and Zinc Alloys. New York: Marcell Dekker; 1994.

4. Barnhurst RJ, Beliste S. Corrosion Properties of Zamak and ZA Alloys. Quebec: Noranda Technology Centre; 1992.

5. Shreir LL, Jarman RA, Burstein GT, eds. Corrosion. 3rd ed. Oxford: Butterworth-Heinemann; 2000.

6. Hihara LH. Corrosion of metal-matrix composites. In: Cramer $\mathrm{SD}$, Covino BS Jr, eds. ASM Handbook Volume 13B, Corrosion: Materials. Materials Park: ASM International; 2005 p. 526-542.

7. Bobic B, Vencl A, Babic M, Mitrovic S, Bobic I. The influence of corrosion on the microstructure of thermally treated ZA27/SiCp composites. Tribology in Industry. 2014;36(1):33-39.

8. Girish BM, Prakash KR, Satish BM, Jain PK, Devi K. Need for optimization of graphite particle reinforcement in ZA-27 alloy composites for tribological applications. Materials Science and Engineering: A. 2011;530:382-388.

9. Seah KWH, Sharma SC, Girish BM. Corrosion characteristics of ZA-27-graphite particulate composites. Corrosion Science. 1997;39(1):1-7.

10. Sharma SC, Somashekar DR, Satish BM. A note on the corrosion characterization of ZA-27/Zircon particulates composites in anodic medium. Journal of Materials Processing Technology. 2001;118(1-3):62-64.

11. Sharma SC, Seah KWH, Satish BM, Girish BM. Corrosion characteristics of ZA-27/glass-fiber composites. Corrosion Science. 1997;39(12):2143-2150.
12. Bobic B, Mitrovic S, Babic M, Vencl A, Bobic I. Corrosion Behavior of As-cast and Heat treated ZA27 Alloy. Tribology in Industry. 2011;33(2):87-93.

13. Bobic B, Bobic I, Vencl A, Babic M, Mitrovic S. Corrosion behavior of compocasted ZA27/SiCp composites in $\mathrm{NaCl}$ solution. In: 14th International Conference on Tribology, SERBIATRIB '15; 2015 May 13-15; Belgrade, Serbia. p. 67-72.

14. Karthick J, Rama T, Mani Bharathi N. An Experimental Study on Usage of Quarry Rock Dust as Partial Replacement for Sand in Concrete. International Journal of Advance Research in Education Technology. 2014;1(1):41-44.

15. Alaneme KK, Aluko AO. Fracture toughness (K1C) and tensile properties of as-cast and age-hardened aluminum (6063)-silicon carbide particulate composites. Scientia Iranica. 2012;19(4):992-996.

16. Daoud A, Abou-Elkhair MT, Rohatgi P. Wear and friction behavior of near eutectic $\mathrm{Al}-\mathrm{Si}+\mathrm{ZrO} 2$ or WC particle composites. Composite Science and Technology. 2004;64(78):1029-1040.

17. Aku SY, Yawas DS, Apasi A. Evaluation of cast Al-Si-Fe alloy/coconut shell ash particulate. Gazi University Journal of Science. 2013;26(3):449-457.

18. Pai BC, Ramani G, Pillai RM, Satyanarayana KG. Role of magnesium in cast aluminum alloy matrix composites. Journal of Material Science. 1995;30(8):1903-1911.

19. Constantinescu V, Taran RG, Bogus GV, Carcea I. Reinforcement Corrosion to Aggressive Environment. Advanced Materials Research. 2014;1036:71-76.

20. Almomani M, Hayajneh MT, Draidi M. Corrosion investigation of zinc-aluminum alloy matrix (ZA-27) reinforced with alumina (A12O3) and fly ash. Particulate Science and Technology. 2017;35(4):439-447. DOI: 10.1080/02726351.2016.1165321 